Il seguente articolo é stato scritto con un co-autore (Rossella Schillaci).

L'apporto individuale alla pubblicazione è suddiviso come segue:

- Introduzione e conclusione sono state redatte in comune.

- (da pag. 237 a pag. 242): la sezione che inizia con il sottotitolo "Things from afar: the testimony of two Paraguayan women from inside Italian prisons" é stata scritta interamente da Valentina Bonifacio.

- (da pag. 242 a pag. 247): la sezione che inizia con il sottotitolo "Imprisoned lullaby, the life of a mother and her baby inside an italian prison" é stata scritta interamente da Rossella Schillaci. 


\title{
Between Inside and Outside: Projects of Visual Research inside Italian Prisons
}

\author{
Valentina Bonifacio and Rossella Schillaci
}

\begin{abstract}
This article presents two separate experiences in doing research inside detention centers that are located in two Italian cities. The aim of the article is to discuss how the use of a video camera as a research tool can influence the research context in a situation openly and deeply marked by impotence and disempowerment. Our argument is that besides giving the inmates an instrument to communicate beyond the prison, the use of visual media exacerbates specific aspects that according to the existing literature often occur when doing fieldwork in confinement spaces.
\end{abstract}

The extensive range of studies on gated communities, urban ghettos and ethnic enclaves has highlighted the nature of cities as fragmented spaces, where certain places are seen as more "public" than others and surely more visible. From this viewpoint prisons and gated communities share some features: like gated communities, detention centers are confined spaces that are at once in the city but also removed from it. They rarely become points of reference for the majority of city dwellers and their access is highly restricted. The walls that surround them not only mark an inside and an outside, but they also create a spatial zone of exception that is barely thought about from the outside. If we think about the famous figure of the Panopticon, we realize that what lies behind the walls is never depicted: the Panopticon prison is a monad with no connections to the outside world, a suspended space and time, a floating island beyond the realm of the city. Outside the wall free citizens are prompted to divert their gaze, to avoid questions about what is happening inside. In fact, even when prisons are situated inside the city center a minimum walking distance from the walls is required, with security cameras and barbed wire there to remind people that they should look elsewhere. Countering this trained perceptual denial of detention centers, our projects aim at reinserting them inside the city visualscapes through the use of audio-video equipment.

VALENTINA BONIFACIO is an anthropologist and documentarist; she is currently a MarieCurie fellow at $\mathrm{Ca}^{\prime}$ Foscari (Venice) and The New School (New York). E-mail: valentina. bonifacio@unive.it

ROSSELLA SCHILLACI is a filmmaker with a M.A. in Visual Anthropology from the University of Manchester. She has produced documentary films with Azul [www.azulfilm.com]. E-mail: doc@ azulfilm.com

Color versions of one or more of the figures in the article can be found online at www. tandfonline.com/gvan. 
Social anthropologists have often highlighted the difficulties in carrying out participant observation inside prisons [Rhodes 2001]. "The Curious Eclipse of Prison Ethnography in the Age of Mass Incarceration" is the title of a polemic article by Loï Wacquant [2002], and "Resisting the Eclipse" was the title of a conference on prison ethnography held at The Open University in the UK in 2012 [cf. Drake, Earle and Sloan 2015]. As Hammersley has pointed out, even though "the distinction between inside and outside is central to much discussion of ethnography" [2015: 21], the limits between these two realms are never as clear as when doing prison ethnography. According to him, doing ethnography in such contexts exacerbates the tensions and critical aspects that already belong to the discipline. In our experience, the same is even more evident when using a video camera as a research tool in prisons.

Following Hammersley's suggestion, we will show how the use of visual media exacerbates some specific aspects that are already embedded in visual ethnographic practice and that are linked to what we might call "the status" of the camera. According to the anthropologist Silva Paggi, the status of the camera in fieldwork is potentially different from that of the cameraman. The camera is often perceived not as a mere "object," in fact, but as a third person coming between the cameraman and the filmed subject, and it creates a different set of expectations and a different network of relationships with respect to those of the researcher [Bonifacio 2013]. In this article we will show two different experiences of doing visual ethnography with a video camera. The first research project-which led to the experimental film Things from Afar [2015] — has been developed by Valentina Bonifacio with two Paraguayan women imprisoned in Milan. The second project was carried on by Rossella Schillaci and concerns the production of an observational film amongst mothers who are living in prison with their children inside the special section of a detention center in Turin, which was edited into the film Imprisoned Lullaby [2016].

The privileged status of the cine-camera has been a powerful intervention in establishing a direct and intimate contact with the inmates on the one hand, and for negotiating our presence inside the detention centers on the other. In fact, according to the Italian Ministry of Justice, any person who is not related to the inmates through kinship is a "third person" and needs to present "reasonable causes" in order to meet them. ${ }^{1}$ Moreover, it is the prison director who decides if the reason presented by that third person is reasonable or not, and if the encounter is in the end possible. For both of us the use of a video camera provided from the start a "reasonable cause" for being inside the prison. Unlike what usually happens when doing research in other contexts, though, where the anthropologist slowly negotiates the use of a camera with the subjects of a documentary while establishing a relationship with them, in the case of a prison the subjects have to give a written "informed consent" sometimes even before knowing the researcher. The anthropologist and the subjects of the film switch from a thin or non-existent relationship to a very intimate and intense one.

Another characteristic of documentary filmmaking, the awareness on the part of the subjects of being filmed, their pro-filmic attitude [Paggi 1993] in front of the camera, also gets exacerbated when filming in prisons. As we hope to make clear, this is due to the peculiar context of detention centers where inmates-at least 
those who haven't been sentenced for life-consider their everyday life as a temporary condition to be overcome and perhaps even forgotten. In such a space, where the idioms of "inside" and "outside" are constantly deployed by inmates to make sense of the world and of their position in that world, the camera can broadly stand for the "outside." The inmates are thus particularly aware all the time about what content they want to pass on to the outside world. It is in an altered temporal dimension-where affective states are experienced in a particularly intense way and the spatial and temporal dimensions are radically distorted-that the encounter between the researcher, the inmates and the camera takes place.

\section{THINGS FROM AFAR: THE TESTIMONY OF TWO PARAGUAYAN WOMEN FROM INSIDE ITALIAN PRISONS}

In 2010, around 100 Paraguayan women were being held in Italian prisons, mainly for crimes related to drug smuggling. Having lived in Paraguay for many years, one of us (Bonifacio) decided to meet some of them and to understand what it meant for them to be far from their country, sharing memories of landscapes and tastes. When I decided that making a documentary would be a good excuse-my "reasonable cause" for meeting them at first-I got in contact with the Paraguayan embassy and asked them to deliver a letter to the inmates. In the letter I explained that I wanted to meet them in order to make a documentary about what it meant to be "caught in nostalgia," and what memories of Paraguay now haunted their everyday life. Contrary to what would usually happen during fieldwork, I had to define the terms of my relationship with the people I wanted to meet before even knowing their names. Thus before even starting the research I began to experience the thick line which separates the inside from the outside. For its part the Embassy decided to support me because they wanted to discourage more women from Paraguay from illegally transporting drugs to Italy. They sent my letter to a group of selected inmates, and some responded positively. Nevertheless, the time lapse that occurred between getting the informed consent on the part of the people and the official permission to get into the prison was considerably longer than expected. When the encounters finally happened, after more than one year, both the researcher and the inmates had been imagining the situation over and over again, rehearsing words and expressions while waiting for the actual interview. I thus finally managed to interview only two women in two different detention centers on the outskirts of Milan, whom I will now call Gladys and Maria. This stretching of time was already a clue to the stillness that the inmates were forced to experience inside the prison on a daily basis, reflecting the passage of time, a constant wait as they were experiencing it.

Unlike other research projects in prisons [Whetter 2015], my role was not ambiguous, nor was my status as an outsider ever called into question. My encounters with the inmates happened in neutral spaces, an empty room with a table and two chairs, a-personal and suspended in time and space. A guard accompanied me through several gates and corridors, each time closing and opening doors. I felt the responsibility and the pressure of my privileged 
position, of being able to enter a space that was closed for most of the residents unless they could be able to formulate a precise reason to be there. My camera became my excuse and my refuge: I was there in order to allow the inmates to get in contact with the outside world.

In the Palgrave Book on Prison Ethnography the editors state that they "contrast an ethnographic approach with purely interview-based research methodologies that tend to be episodic, short lived and often take place outside spaces the informant routinely occupies" [Drake, Earl and Sloan 2015: 3]. Nevertheless, I consider that my fieldwork in the prison was not confined to the moment of the interview: it started much before, in the coming and going of letters and permissions that defined the rules of the space where my encounters would take place-a space where only one of the interlocutors had been deprived of her liberty and experienced "constraint on freedom and being locked up and under control" [ibid.].

Getting access to the space of the interview meant starting to familiarize myself with a context where different rules of surveillance and autonomy applied. I wasn't sure about how to start the dialogue, and had prepared a few questions to get the conversation going. Nevertheless, when the encounter happened there were no presentations or silences: both women started to speak without even waiting for the camera to be switched on, their words coming like a river, hints of a discourse reimagined and rehearsed several times. Contrary to my expectations they did want to talk about how and why they ended up in prison, and about what happened to them while being confined inside the detention space. Being "criminals" was their new identity, the one they had to challenge and keep under control. In both cases, the women were struggling between their own perception of themselves as honest people and the label of "criminal" they had received once inside the prison, as if "who" they were was not decided by what they did in their life up to that moment and why, but rather by where they were now forced to live. Crossing the line between the inside and the outside meant becoming a criminal, independently from whom they felt they really were.

As none of them wanted to be easily recognizable, they allowed me to record their voices but not their faces. I used my camera to record the interviews, but with the lens cover on. Everything had been unconventional during my fieldwork. First of all, I hadn't met the subjects of my research in the context of their everyday life: I met them in an empty room, with no objects around us, nothing that could help us to rely on the sensorial qualities of an encounter. Second, even if it took me nearly a year to negotiate and arrange the encounters, they lasted less than a couple of hours each. Rather than taking place in a relationship with the people, I had the impression that most of my fieldwork took place inside the space of my own imagination, during the long period when I was preparing myself for the encounter. Because of this, confronted with the absence of images and with the overwhelming role of imagining and fantasizing in my relationship with the inmates, I decided to dwell in that space of imagination and to ask a visual artist, Lucia Veronesi, to help me in visualizing the encounter, to give it corporeality.

There has been a growing literature on the collaboration between artists and anthropologists over the last decade. The reasons behind these collaborations 
are multiple, and often related to an increasing attention to the sensorial domain [Schneider and Wright 2013]. In the case of this collaboration with Veronesi the collaborative process was triggered by the lack of images. Together we created some animations that would accompany the oral narrative of the women. As Grossman explains about her collaboration with the visual artist Selena Kimball, we decided that animations and oral narratives didn't have to literally "represent or illustrate each other" [Grossman 2015: 141]. As Veronesi explains: "I did not want the images to be a descriptive and plainly explanatory accompaniment to narration. I would rather give images an autonomous energy by creating a gap between the fragmentary talks and the visions they conjure up. My aim was to create gaps that let the eye pause from reading the subtitles and let the mind ponder on the words recently read and told towards dreamlike visions" [Lucia Veronesi interview, 2015]. The final images produced represent a further conceptual elaboration with respect to the interviews: they are the result of long hours of dialogue and exchange between me, Veronesi and the video-editor Silvia Pellizzari.

In the case of Maria, for example, Veronesi decided to interpret visually my own "anthropological" considerations on how she portrayed herself in the interview. In fact, she portrayed herself and justified her presence in the prison in a way that reminded me of the personage of the Virgin Mary. A deeply religious person, she was sacrificing herself for her son, whose debts had forced her into drugs trafficking, and was embracing a virgin-like attitude by giving unconditional love to all the young Paraguayan women who shared the space of the prison with her. The animation that Lucia created was thus based on an image of the Paraguayan Virgin of Caacupé. Maria's troubled relationship with her son "who continuously calls her to ask for money and bids her to go back home," also elicited other images on the part of the video artist. "In her attempt to move away from her son, Maria was supported in the prison by a psychotherapist. In the sequence accompanying her words, the dreamlike image definitely wins over a more explanatory and narrative one. The camera films with circular movements a set of empty rooms, abandoned and spare spaces without windows. I created these miniature rooms with paper and cardboard in an attempt to figure out the meaning of being in a confined space with one obsessive thought and without being able to find a way out" [Veronesi interview, 2015]. In the finished video, staging a dialogue between our imaginations, Lucia's images of empty rooms are followed by that of a building while an image of the Virgin slowly takes shape [Figure 1].

The detachment from the surrounding context, the suspended state of being inbetween places, is addressed in the images accompanying the second interview. As Veronesi explains: "Gladys too talks about her children. She did not tell them where she really is, and let them believe she is working in Italy. While her words appear on the screen, we can see a city skyline in a distance, gradually replaced by rocky shapes that slowly stand above. I worked with collage and stop motion to underline Gladys' distance from the outer world and from reality, which remains unreachable and submerged" [Veronesi interview, 2015]. In this case the artist chooses to represent in her animation Gladys' temporary forced suspension from motherhood, her impossibility to communicate with her children, to explain to them what is truly happening. In fact, she can only make one phone 


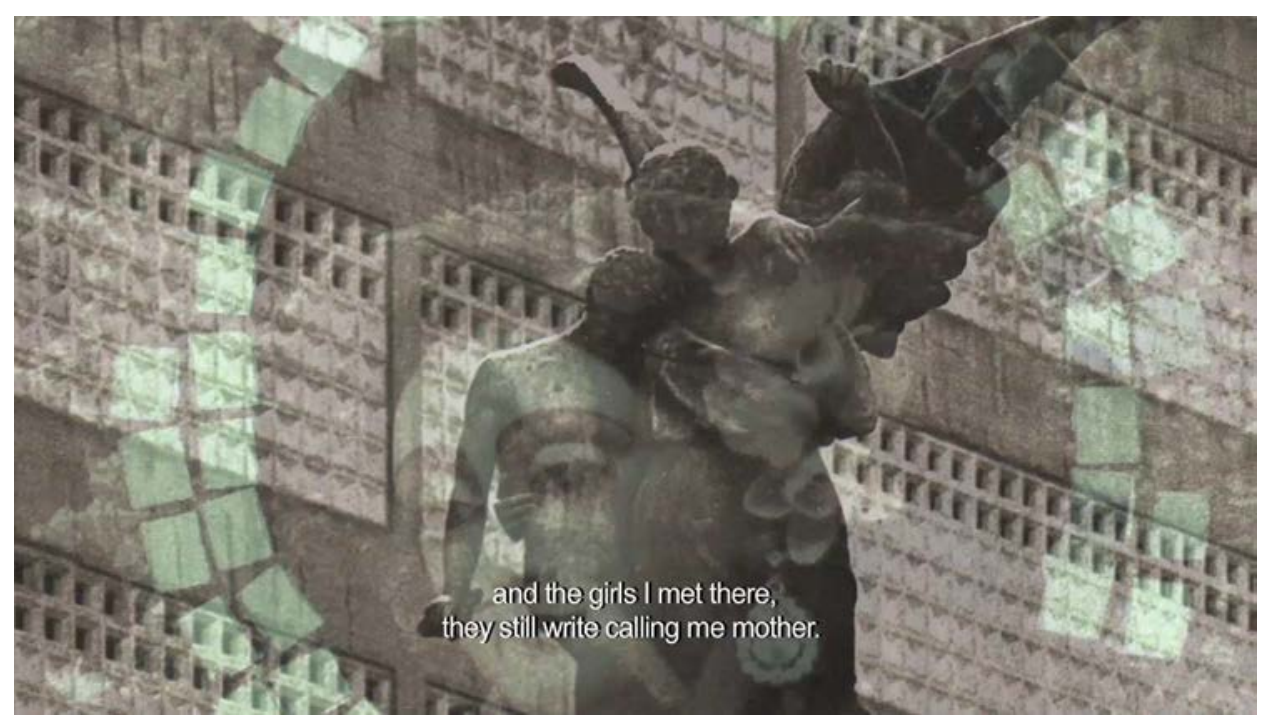

Figure 1 Still frame from Things from Afar. The virgin of Caacupé slowly emerges from a prison wall while Maria talks about other Paraguayan inmates, younger than her, with whom she built strong affective relationships to the point that they call her "mother." (Photo () L. Veronesi and V. Bonifacio)

call per week, which means that she talks to her mother one week and to her two sons the following one. Each fortnight, when she talks to her sons, she portrays herself as a common immigrant worker in Italy. At the same time, she knows that calling them once every two week is not what a "regular" mother would do, that she should have a cellphone, a house, a number. She knows they might be imagining something else, and she's afraid of that [Figure 2].

At times my expectations conflicted slightly with Lucia's. My initial concern was sticking as much as possible both to the image I had of Paraguay and to the images that circulated in the mail-exchange I had with Gladys and Maria after the visit (I sent them pictures of Paraguayan landscapes and received drawings in exchange). On her part Lucia felt freer to evoke images that emerged from her own personal feelings and associations. In her words: "images seem to come unconsciously from the prisoners' inner selves and can be associated with a stream of memories, nostalgia and anger that materializes as the story unfolds" [Veronesi interview, 2015]. A similar tension was experienced by the anthropologist Alyssa Grossman in her collaboration with Selena Kimball. In that case the animations that Kimball created with the objects that Grossman collected during fieldwork in Romania, the artist wanted to be free to interact with the objects independently from what they meant for their original owners, to let the sensorial qualities of the objects talk to her rather than "intellectually processing them" [Grossman and Kimball 2009: 16]. Kimball too, like Veronesi, was not afraid of creating visual imaginaries that did not coincide with those of the ethnographic subjects. Even though her attitude initially clashed with mine, I eventually came to the realization that unless the inmates themselves would have produced the 


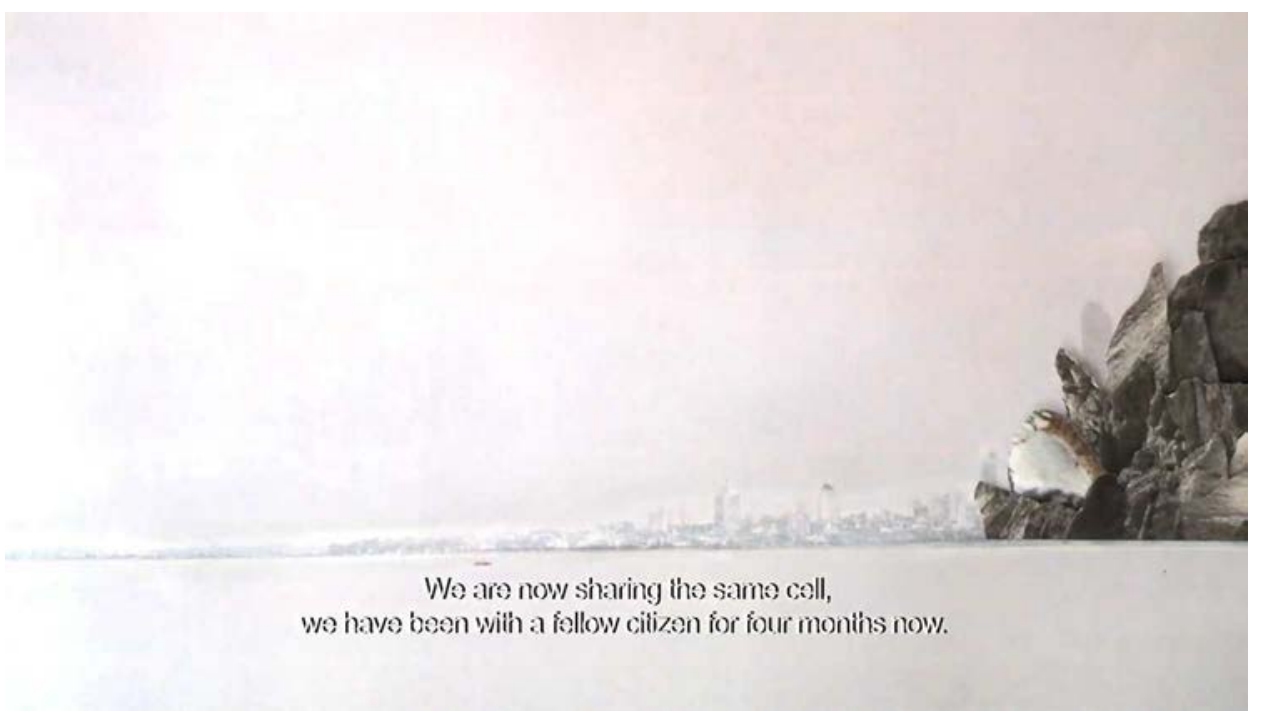

Figure 2 Still frame from Things from Afar. A city skyline fades in the background while big rocks start emerging from the sea in front of it. After remembering tastes and colors from Paraguay, Gladys's storytelling focuses once again on her present days in the detention center. (Photo (c) L. Veroesi and V. Bonifacio)

animations any kind of image would have been an arbitrary one. The final result was thus the outcome of an interaction between four people: me, the women and Veronesi. The fact that it was an interaction rather than a dialogue mirrored the level of fragmentation that marked the whole process since the beginning: that two of us were outside and two were inside.

The "inside" was a world we would never have access to, a world that functioned according to different rules. We could think about the presence of a video-camera in that particular context and with those modalities as a crack in the wall that was separating the prison from the city, but in no way as a temporary obliteration of that wall. When I screened the documentary to Maria in Paraguay (Gladys had decided to start a new life in Bolivia), in March 2016, she liked it and she said it managed to convey her feeling at that time, but she also said that she was actively trying to forget almost everything she had experienced. Of the last period of her incarceration she remembered a blue wall, and nothing else. She said she had been imagining for months the moment where she could finally step out of the prison alone and walk around the streets of Milan just like any other "normal" Italian person. But that moment never came: in fact, she was finally escorted from the prison in Milan where I interviewed her to a temporary detention center, and from there directly to the airport and back to Paraguay. She could never experience the city as a free citizen, and she felt sad and humiliated about it. When I met her in Paraguay, she preferred not to tell me how it was her first day back in her country. After making a few comments about the film she moved on to talk about her house, her job, her family, and all 
the things that make up a normal life and that we could have never discussed when we met "inside."

\section{IMPRISONED LULLABY, THE LIFE OF A MOTHER AND HER BABY INSIDE AN ITALIAN PRISON}

The second project, which ended in the editing of the documentary film Ninna nanna prigioniera [Imprisoned lullaby, 2016], was filmed inside the "mothers' section" of the Turin prison. Under the provisions of Italian law, imprisoned mothers are allowed to keep their children in a nursery unit of the adult jail till the child is 3 years old, after which the child is taken out of jail, separated from the mother, and placed in the care of a family member if one exists, in a special institution for lone children, or in another family. ${ }^{2}$

There are conflicting views about whether children should live in a prison. As some research shows [Alejos, Brett and Zermatten 2005], many European prisons have adopted a policy of compromise, accepting that while the prison environment is unsuitable for children, it may be best for a very young child to remain with his or her mother rather than be separated [Caddie and Crisp 1997]. In June 2000 the European Parliamentary Assembly adopted a recommendation, in which it recognizes the "adverse effects of imprisonment of mothers on babies." It goes on to state that "early maternal separation causes long-term difficulties, including impairment of attachments to others, emotional maladjustment and personality disorders," and that the development of babies is retarded by restricted access to varied stimuli in closed prisons. ${ }^{3}$ Hence the aim of the documentary was to examine the experience of motherhood and early childhood spent in imprisonment.

The first general questions raised when I was making the research were: How does the daily care of a mother for her child get modified within the space of a prison? How can they, for instance, put their child to sleep while locked in the narrow confines of the cell, where there's hardly space to walk? Which strategies do the mothers adopt to build an intimate relationship in the controlled prison environment? And how do children perceive the modified space-time of the prison? How do they interact with it?

While waiting for authorization to enter the prison and meet the inmate mothers, I (Schillaci) began my project by getting to know all the associations and the social workers who work inside. A long period of research was spent in a municipal nursery, outside the jail but in the same neighborhood, where two educators used to bring the "imprisoned" children for a few hours each morning. When finally the authorization arrived, it had very strict conditions. For the first 6 months that I was authorized to enter the prison, it was only to do research and meet the mothers, without any permission to make a sound or video recording. However, special permission was given to bring some printed pictures of the children taken inside the nursery, after having passed the guards' control. These pictures helped me in meeting with the mothers and explaining my project to them. For the inmate mothers, the pictures were the only way to know what happened to their children while they were outside the cell, and 
for me these pictures were an instrument to get "inside" and begin a relationship with the mothers. Like other researchers [Jewkey 2012], I kept a diary in order to better understand how the rules of a closed system such as a jail affect others and also myself.

At that time my son was the same age as some of the children in the prison. I couldn't help comparing the attitude and the behavior of those children's "inside" and "outside," but my disturbed feelings, far from dissipating, became a way to go deeper in the research topics. During the first period I listened to the mothers telling me how hard the prison was for their children: all that iron, the iron of beds, doors, bars, where children constantly bump, the confused eating times, the dirt. And how hard it was for them to hold their children always tight, to prevent them from running away every time the gate gets opened, or to prevent them from making too much noise in the corridors lest the guards write a report.

The time I could spend inside the jail was limited. The authorization lacked written formal indication about "time" or "places" that would limit the researcher's activities; and therefore I was treated like a normal "visitor" by the guards and obliged to follow the usual rules: I could stay inside the prison for only a few hours a day, often just in a common area in the corridor and not inside the cell. During that period it was also difficult for the inmates to accept just being "observed," since they wanted to speak and they often requested to be "interviewed." In particular, it was strange for them to stay for so long in a common space such as the corridor. Their normal everyday life was mostly inside the cell, and if I wanted to observe and interact (and not only interview them) I couldn't confine the research to outside the cell. In this sense, there is a clear difference between doing research inside and outside. In fact it is much less "reasonable" that someone spend time hanging around inside a prison, and there are very little in the way of everyday activities to engage with, apart from playing with the kids. Consequently I asked for a second authorization, so as to be able to film inside the cell rather than only in the common place, and for a longer time. In order to get this, I explained the aim of the project-namely and simply to show through images the everyday life of children and mothers in jail-to both the Prison Director and the mothers. I believe they both accepted this for the same reason: they wanted to show this difficult situation to the outside world. One of the reasons why the Prison Director, in particular, agreed to authorize the documentary project was because he wanted to encourage the building of a special section only for mother and children, the ICAM. These kinds of structure were approved by law, but their construction was postponed by the State due to a lack of funding.

After getting the authorization to go inside with a video camera my research could finally take a big step forward. In fact, only by spending a long time observing the everyday life of mothers and children with the camera did I start to see and understand their words and be able to represent what they tried to convey in words with images and sounds. The mothers accepted the fact that I could spend time looking at them without the need to speak, because I was simply doing my job and they would allow me to do that. They watched some of the footage and understood the project and my approach. For them, the result of this 
long process of research, namely "the film," was important: it was a way to tell the outside world about the harsh situation in which they and their children were forced to live. They understood the power of the images, as compared with words. On one occasion when I screened a long scene with the family eating inside a small cell, the mother told me that only while watching those images did she begin to realize how really bad it was for their children to live in that environment [Figure 3].

After getting a final authorization from some mothers to be filmed for a longer period during the day (from $8 \mathrm{am}$ to $8 \mathrm{pm}$ ) and over many months, I started to work toward creating an observational film. I decided to focus on one mother with two kids in order to go deeply into her story, and to follow her during the waiting for the legal process and for the house arrest. I had with me a female camera operator who was shooting, while I was directing and recording the sound with a directional microphone.

The camera was hand-held and followed the characters up close, accompanying them over the course of their day. Most of the time we used a $50 \mathrm{~mm}$ lens, in order to be physically close when shooting, so that all the inmates knew exactly what and whom the camera was framing, as contrasted with surveillance cameras that covered the prison spaces in wide angles. Inmates who didn't want to be filmed could easily check the situation and stay far off. In crowded situations the camera was kept at a very low angle, following the children while avoiding the faces of people. The children were filmed at their own height also in other situations, as if to convey their visual angle in order to portray the prison as seen through their eyes. For example, they were followed by the camera as they walked around the outdoor courtyards and the roadways inside the walls, which appeared infinitely high compared with their own size. By shooting their daily routine, the children's discoveries, the relationship between them and their

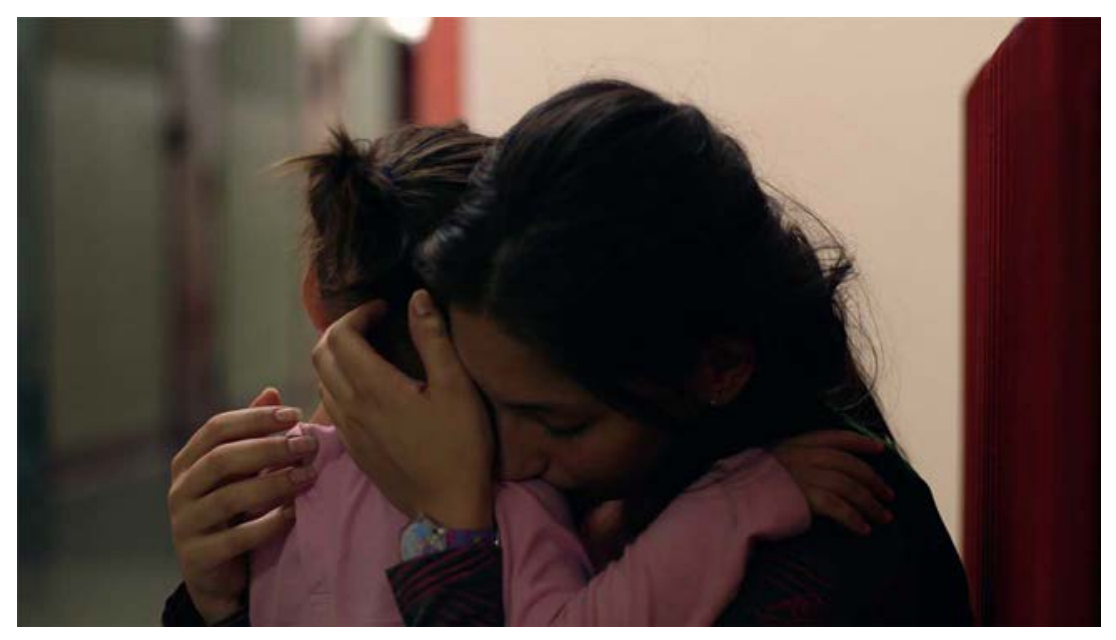

Figure 3 Still frame from Imprisoned Lullaby. A moment of the scene of the ending of dinner, taken in the section corridor, while the children are playing and the mothers are waiting. (Photo (c) Rosella Schilacci) 
environment, together with ambient sounds and noise, the idea was to enter the prison cell with them, and living from their point of view [Figure 4].

Often we, the camera operator and I, felt embarrassed because in some way we were "occupying" the already very small spaces of the mothers. For security reason the guards didn't allow us to step in and out of the jail as we needed. After a long period we managed to create a good relationship with some of the guards, who understood our methods of work and decided to help by giving us an empty cell in order to put our technical equipment there or to rest. As we were in jail from morning to evening without having permission to go out, and we eventually obtained our own cell like all the other inmates, I started to think that we had managed to become insiders in our field of research. This assumption though was deeply challenged when I once told a mother that I was going into "my" cell. She got quite upset and she told me not to say "my," because I wasn't incarcerated, since in the evening I was free to go home to my house. Her reaction was a big revelation for me and it helped me reflect about the absurdity of my condition: I had been allowed to stay all the day in "the graves of the living," as defined by David Scott [2015], and yet come back every night to the world of those "alive." I was held in jail and yet happy to be there, as I thought it was the only way to make a good observational film. After awhile, though, coming back home at night was paradoxically becoming harder and harder, as I couldn't stand the privilege anymore of staying in two such different worlds.

Jennifer Sloan and Serena Wright [2015] write about the difficulties not only of gaining access to prison, but also of "getting out" when the time comes to leave the field behind. In some respects we felt it a great embarrassment to leave in the evening after a full and intense day spent with the mothers and the children. A deep sense of guilt plagued us when the guards locked the cell of the people we were freely talking with only 5 minutes before, and after 8 pm we could only say

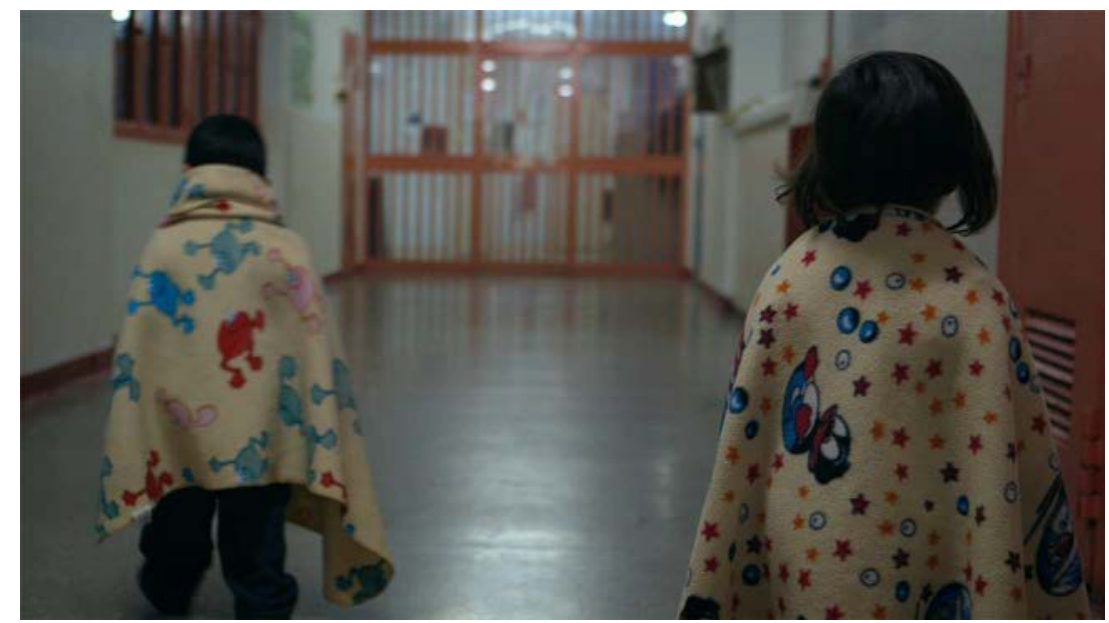

Figure 4 Still frame from Imprisoned Lullaby. The children are wandering in the corridor, the camera is shooting them at their level, at a very low angle: it's following their walk, in order to allow the viewer to see the environment from their perspective. (Photo (C) Rosella Schilacci) 
Hello through the bars. We needed a long time of "decompression" before being able to come back to our "normal" lives and homes, to forget all the small moments of humiliation and violence that we witnessed (and without being able to change it or say anything), all the suffering we listened to, to re-adapt to different rules of behavior between human beings. As Sloan and Wright underline, "getting out-and getting away mentally intact-is an important process that is rarely discussed in the research literature" [ibid.: 153]

In the first two months of fieldwork and shooting we were able to capture the "resilience" of the inmates, their humor and energy enlivened by the vital force of their children. It was a time of comparison and exchange between these young mothers and "we" of the crew: women with quite different life stories. I believe that at first our presence inside the jail helped the mothers and their children to endure the harsh environment which we temporarily shared, appreciating our commitment to spend so much time with them and participating in the big "adventure" of making a documentary. It also helped the mothers not to think so much about their long wait, and to have some moments of relief in between so many moments of sorrow. Nevertheless, after a few months of shooting the legal situation of one of the mothers who had become the main protagonist of the film worsened, and her suffering, like that of other women, increased significantly. Both the mothers and I were caught between the need to show and "shout out" the pain caused by the judicial system, and the desire to find a way to not be overwhelmed by the situation. I have come up against the limits of the observational approach in such a sensitive context, as I had to deal with several critical issues: For how long is it possible to observe sorrow? What is the right position of researchers and filmmakers, in a context where they sometimes witness the abuse of power and control by authorities? Is it possible for them not to interfere? How can we shoot in an intimate way with a person with whom we have built a strong relationship, without being able to do anything to help her solve her problems? The camera helped me to enter in an intimate way inside a "closed" world like the prison, but then after awhile it also showed all the limits of these labile connections.

After being denied house arrest, the main personage of the documentary was emotionally destroyed. Together with her and the camera person, we decided that there was no more space for us and that we had to stop shooting. It was too hard in fact for her to continue to be filmed in such an intimate way during that unbearable pain and while being "viewed" not only by us but also by the "public" who would have watched the documentary once it was finished. At the same time, it was unsustainable for me to keep sharing her emotions without being able to help at all and without any right to "interfere." After that, I needed a long time to come to terms with the experience, and to finally edit all the materials more than a year later. Retrospectively, I consider that this kind of intimate experience in a prison might benefit from supervision and discussion within a bigger team of researchers, teachers and specialists who could help in analyzing and assessing the whole process.

When the film was finished, more than two years after the shooting, I asked the mothers who were already out of jail if they wanted to see the film, but they didn't. They told me that they were very happy if other people could see how 
their living conditions had been in the cell, but as far as it concerned them they only wanted to forget and obliterate that period from their lives.

\section{CONCLUSION}

Our two examples show two very different ways of using a camera in the context of detention centers, and in particular in the case of doing prisoners' ethnography rather than any of the staff or organization. In both cases, the camera provided a useful tool to get inside the prison without creating confusion over the role of the researcher, who was by no means to be confused with a staff member: in a context where roles are clearly marked, the identity as "documentarist" provided a safe refuge from which to engage in a dialogue. On the other hand, it created an instant barrier when the persons didn't feel good enough to show how they felt to a wider public, which is something quite frequent in that particular context. The use of the camera inside a detention center exacerbates the contrast between being on and off camera, stressing once more the difference between being inside and outside.

\section{NOTES}

1. https://www.giustizia.it/giustizia/it/mg_3_8_3.wp

2. Report. Children of imprisoned parents [2011], published by the Danish Institute for Human Rights, European Network for Children of Imprisoned Parents, University of Ulster and Bambini senza sbarre NGO.

3. Recommendation 1489 [2000] Mothers and Babies in Prison.

\section{REFERENCES}

Alejos, Marlene, Rachel Brett, and Jean Zermatten

2005 Babies and Small Children Residing in Prisons. Geneva: Quaker United Nations Office.

Bonifacio, Valentina

2013 Le statut ambigu de la caméra: une réflexion sur l'utilisation de la caméra vidéo dans le cadre d'un travail de terrain avec les Maskoy dans la région de Chaco au Paraguay. Mondes Contemporains. Revue d'anthropologie sociale et culturelle, 3: 13-30.

Caddie, Dianne, and Debbie Crisp

1997 Imprisoned Women and Mothers. London: HMSO; [Home Office Research Study 162].

Drake, Deborah H., Rod Earle, and Jennifer Sloan

2015 General Introduction: What Ethnography Tells Us about Prisons and What Prisons Tell Us about Ethnography. In The Palgrave Handbook of Prison Ethnography. Deborah H. Drake, Rod Earle and Jennifer Sloan, eds. Pp. 1-20. Basingstoke: Palgrave Macmillan; [Palgrave Studies in Prisons and Penology].

Grossman, Alyssa

2015 Forgotten Domestic Objects. Home Cultures, 12(3): 291-310.

Grossman, Alyssa, and Selena Kimball

2009 Memory Objects, Memory Dialogues. Reconstruction, 9(1): electronic resource (http:// reconstruction.eserver.org/Issues/091/grossman\&kimball.shtml)

Hammersley, Martin

2015 Research 'Inside' Viewed from 'Outside': Reflections on Prison Ethnography. In The Palgrave Handbook of Prison Ethnography. Deborah H. Drake, Rod Earle and Jennifer Sloan, 
eds. Pp. 21-39. Basingstoke: Palgrave Macmillan; [Palgrave Studies in Prisons and Penology].

Jewkey, Yvonne

2012 Autoethnography and Emotion as Intellectual Resources: Doing Prison Research Differently. Paggi, Silvia Qualitative Inquiry, 18(1): 63-75.

1993 À propos de l'interview filmée dans la recherche anthropologique. In Memory and Multiculturalism, VIII International Oral History Conference, Lucca-Siena, Pp. 202-220. Siena: Comitato Internazionale di Storia Orale.

Rhodes, Lorna A.

2001 Toward an Anthropology of Prisons. Annual Review of Anthropology, 2001: 65-83.

Schneider, Arnd, and Christopher Wright (eds.)

2013 Anthropology and Art Practice. London, New Delhi, New York and Sydney: Bloomsbury. Scott, David

2015 Walking amongst the 'Grave of the Living': Reflections about Doing Prison Research from an Abolitionist Perspective. In The Palgrave Handbook of Prison Ethnography. Deborah H. Drake, Rod Earle and Jennifer Sloan, eds. Pp. 40-58. Basingstoke: Palgrave Macmillan; [Palgrave Studies in Prisons and Penology].

Sloan, Jennifer, and Serena Wright

2015 Going in Green: Reflections on the Challenges of 'Getting in, Getting on, and Getting out' for Doctoral Prison Researchers. In The Palgrave Handbook of Prison Ethnography. Deborah H. Drake, Rod Earle and Jennifer Sloan, eds. Pp. 143-168. Basingstoke: Palgrave Macmillan; [Palgrave Studies in Prisons and Penology].

Wacquant, Loïc J. D.

2002 The Curious Eclipse of Prison Ethnography in the Age of Mass Incarceration. Ethnography, 3: 371-397.

Whetter, Lindsay

2015 'To Thine Own Self Be True': Having Faith in the Prison Researcher. In The Palgrave Handbook of Prison Ethnography. Deborah H. Drake, Rod Earle and Jennifer Sloan, eds. Pp. 326-346. Basingstoke: Palgrave Macmillan; [Palgrave Studies in Prisons and Penology].

\section{FILMOGRAPHY}

Schillaci, Rossella (dir.)

2016 Imprisoned Lullaby (original title: Ninna nanna prigioniera); color, 82 mins.; http://www. azulfilm.com/imprisoned-lullaby/

Veronesi, Lucia, and Valentina Bonifacio (dirs.)

2014 Things from Afar (original title: Le cose da lontano); color, 20 mins.; http://www. luciaveronesi.com/luciaveronesiWORKS_26.html 